\title{
Association of a single nucleotide polymorphism of the Leptin gene with growth traits in Takifugu rubripes
}

\author{
Juan Wang ${ }^{1 *}$, Jun Cui ${ }^{2 *}$, Feng Zhang ${ }^{1}$, Xuemei Qiu' ${ }^{1}$, Xiuli Wang ${ }^{1 *}$ \\ ${ }^{1}$ College of Fisheries and Life Science, Dalian Ocean University, Dalian 116023, China \\ 2 State Key Laboratory of Developmental Biology of Freshwater Fish, Hunan Provincial \\ Key Laboratory for Microbial Molecular Biology, College of Life Science, Hunan Normal \\ University, Changsha 410081, China
}

Keywords: Growth traits, Leptin gene, SNP, Takifugu rubripes

\begin{abstract}
Leptin (LEP) plays a role in animal growth, appetite regulation, energy partition, and body composition. In this study, 296 cultivated Takifugu rubripes individuals were screened for LEP gene polymorphisms using PCR-single strand conformation polymorphism (PCR-SSCP) and DNA sequencing. Two single nucleotide polymorphism (SNP) mutations were detected in $T$. rubripes LEP gene: $\mathrm{C} / \mathrm{G}$ at position 232 nucleotide (nt) and C/T at position $310 \mathrm{nt}$. One-way ANOVA of the SNPs and growth traits showed that genotype CC of primer L2 had a significantly higher body length $(B L)$, body weight $(B W)$, and absolute growth rate of $B L(A B L)$ and $B W(A B W)$ than genotypes $C G$ and $G G(P<0.05)$. The genotype frequencies of CC, CG, and GG were $61.15 \%, 35.14 \%$, and $3.17 \%$, respectively. Genotype CC at the C232G site was advantageous and significantly associated with growth traits. This site would be an excellent molecular marker to select and cultivate through statistical analysis. Additionally, the second unmutated and mutated mRNA structures were compared and analyzed. These results indicate that the $T$. rubripes LEP gene may be a candidate for these growth traits.
\end{abstract}

\footnotetext{
* Corresponding author. Tel.: +86-411-84763589, e-mail: xlwang@dlou.edu.cn; \# These authors contributed equally to this work
} 


\section{Introduction}

Leptin (LEP) is known as the hormone product of the obese gene and plays a role in animal growth, appetite regulation, energy partition, and body composition (Zhang et al.,2017). LEP was originally discovered in a mouse model of obesity (Zhang et al.,1994). These mice manifested hyper phagia and extreme obesity due to a homozygous LEP gene mutation. As a candidate gene, LEP gene can be selected based on its participation in growth and muscle development in animal breeding (Lee,2009). Both human and animal studies have demonstrated the close association between body fat, LEP MRNA, and LEP plasma levels(Levin et al.,1996). An increase in fat storage leads to increased LEP gene expression, which thereby inhibits the satiety center in the hypothalamus (Heymsfield et al.,1999). Furthermore, LEP binds to LEP receptors in the hypothalamus, which are signaled through JAK-STAT pathways, alter transcription, and ultimately affect phenotypes. High LEP attenuates and low LEP stimulates appetite (Zhang et al.,1994). Several studies have shown that LEP affects growth, food breeding, and the body fat content in sheep (Delavaud et al.,2000), poultry (Bruggeman et al.,2000), Rattusnorvegicus (Sun et al.,2012), Equuscaballus (El-Maaty et al.,2010), Xenopuslaevis (Crespi et al.,2006), and Macacamulatta (Lujan et al., 2006).

In parts, as compared to studies on LEP gene in farm animals, studies in fish have been limited. Previously, it was proved that LEP affects fish growth, food intake and body fat content in the same way as in mammals ( $\mathrm{Li}$ et al.,2010; Bakshi et al., 2022). Johnson et al. (2000) were the first to suggest that fish express LEP by documenting an LEPimmunoreactive protein. Kurokawa et al. (2005) first cloned Takifugu rubripes LEP(TrLEP). TrLEP cDNA contains a 459 nucleotide (nt) open reading frame (ORF) that encodes a putative polypeptide of 152 amino acids and the primary structure of TrLEP has only $13 \%$ similarity with human LEP gene (Kurokawa et al.,2005). Threading algorithms that used the carbon backbone of the human-LEP crystal structure predicted that the tertiary structure of fish LEP was very similar to mammalian LEP (Zhang et al.,1997; Kurokawa et al.,2005; Gorissen et al., 2009). In mandarin fish, the leptin family contains two members, lepA and lepB. LepB played an important role in food intake and glucose homeostasis regulation, while LepA showed a limited role in gluconeogenesis and lipid metabolism (Yuan et al., 2020).In grass carp liver, LEP acutely reduced the expression of stearoyl CoA desaturase-1, an enzyme critical for the biosynthesis of monounsaturated fatty acids (Li et al.,2010). The food intake of rainbow trout (Oncorhynchus mykiss) was lowered after LEP injection, suggesting that LEP also suppressed food intake mediated by hypothalamic regulation (Murashita et al.,2008). In orange-spotted grouper, six polymorphisms were identified in leptin genes. Three SNPs were associated with growth traits (Wei et al., 2013). Other fish LEPs, including Danio rerio (Gorissen et al.,2009), Oryziaslatipes (Chisada et al., 2014), and Moronesaxatilis (Won et al.,2012), have been identified, and their structures and functions have been investigated.

$T$. rubripes is an economical fish species farmed on its excellent taste, rich nutrition, and high medicinal value in the coastal provinces of Northern China. Recently, T. rubripes cultivation has continuously expanded throughout China. Its culturing methods are evolving rapidly. The present study was planned for correlation analysis on the growth traits of $T$. rubripes using single nucleotide polymorphisms (SNPs) analysis of the LEP gene to advance the culture of $T$. rubripes through molecular marker-assisted breeding.

\section{Materials and Methods}

\section{Animals and traits}

The healthy individuals of $T$. rubripes $(n=296)$ were selected having age of 102 days (d) from Zhuanghe Dalian in China. Their body length (BL), body height (BH) and body weight (BW) were scored according to the methods described by Wang et al. (2014). The muscles of each individual were sampled and preserved in $95 \%$ ethanol for further analysis. 
DNA extraction, PCR amplification and sequence annotation

The genomic DNA was extracted by the phenol/chloroform method and dissolved in ultrapure water with a concentration of $100 \mathrm{ng} / \mathrm{mL}$ and stored at $-20{ }^{\circ} \mathrm{C}$.

Five pairs of primers were designed according to TrLEP (GenBank accession no.: NM_001032725). Primers' information was shown in Table 1. PCR amplification was performed in a reaction volume of $25 \mu \mathrm{L}$ including $1 \mu \mathrm{L}$ genomic DNA, $1 \mu$ Leach primer, $2.5 \mu \mathrm{L} 10 \times \mathrm{PCR}$ Buffer, and $0.2 \mu \mathrm{L}$ Taq DNA polymerase. The PCR thermal cycling condition was initial denaturation for $5 \mathrm{~min}$ at $94{ }^{\circ} \mathrm{C} ; 30 \mathrm{cycles}$ of the $30 \mathrm{~s}$ at $94{ }^{\circ} \mathrm{C}, 52-64{ }^{\circ} \mathrm{C}$ for $30 \mathrm{~s}, 30 \mathrm{~s}$ at $72{ }^{\circ} \mathrm{C}$; and a final 7 min extension at $72{ }^{\circ} \mathrm{C}$.

Table 1 The information of new primers designed for PCR amplification of Leptin gene from T.rubripes

\begin{tabular}{|c|c|c|c|c|}
\hline Locus & Primer sequence $\left(5^{\prime}\right.$ to $\left.3^{\prime}\right)$ & Length(bp) & $\operatorname{Tm}\left({ }^{\circ} \mathrm{C}\right)$ & Location \\
\hline L1 & $\begin{array}{l}\mathrm{F}: \text { :TGCCGACATGGATCACATTC } \\
\mathrm{R}: \text { GGTCCGAAATCAGGTTGTTG }\end{array}$ & 254 & 56 & $58-311$ \\
\hline L2 & $\begin{array}{l}\mathrm{F}: \text { GATGAAGTCAAAGGTGACCTGG } \\
\mathrm{R}: \text { ACAGAGGTGGATCCCTCCAC }\end{array}$ & 114 & 52 & $157-270$ \\
\hline L3 & $\begin{array}{l}\mathrm{F}: \text { TTCGACACCGACAAGGTG } \\
\mathrm{R}: \mathrm{GAAGATATTCCTCCTCGGCC}\end{array}$ & 198 & 57 & $236-433$ \\
\hline L4 & $\begin{array}{l}\mathrm{F}: \text { ACAACCTGAT TTCGGACCGC } \\
\mathrm{R}: \text { CAGCCATGAC TCCCAAACAC }\end{array}$ & 261 & 57 & 294-554 \\
\hline L5 & $\begin{array}{l}\text { F: GGATCTTCT GGAGAGATG } \\
\text { R: CCATITTCT CTGTCGGCGC }\end{array}$ & 284 & 60 & $502-785$ \\
\hline
\end{tabular}

PCR-single strand conformation polymorphism (PCR-SSCP) and DNA sequencing were used to perform genotyping. One microliters of the PCR product was diluted with $5 \mu \mathrm{L}$ of loading buffer (98\% formamide, $10 \mathrm{mM}$ EDTA pH8.0, $0.025 \%$ xylene cyanol $\mathrm{FF}, 0.025 \%$ bromophenol blue, $2 \%$ glycerol). After denaturing at $98{ }^{\circ} \mathrm{C}$ for $10 \mathrm{~min}$, the mixture was immediately placed on ice for $10 \mathrm{~min}$. Next it was loaded on a $10 \%$ acrylamide/bisacrylamide gels (acr:bis $=29: 1$ ). The PCR product was electrophoretically resolved $(10 \mathrm{mV} / \mathrm{cm}$ for $14-16$ hours). The gel was stained using the silver staining method. Each homozygote PCR product was purified, recovered, and sequenced using the Sanger sequencing method in TaKaRa Biotechnology (Dalian) Co. Ltd. (TaKaRa Dalian).

The second structure of TrLEP MRNA

All the second structures of TrLEP mRNA were predicted by the software (Reuter and Mathews, 2010).

\section{Statistical analysis}

Absolute growth rate was calculated according to the equation described by Wang et al. (2010):

$A B L / A B W=y / t$

where $y$ was $B L$ or $B W$, and $t$ was the age in days ( $t=102 \mathrm{~d}$ ).

The body length, body height, body weight, $A B L$, and $A B W$ of the $T$. rubripes were scored, and the data were analyzed by one-way ANOVA through software SPSS 14.0. The correlation between the SNPs and growth traits were analyzed through post hoc multiple comparisons (Duncan method, P-value $<0.05$ ). 
A fixed model was adopted according to the factors that affect growth traits using the following equation (Wang et al., 2014):

$y_{i j}=\mu+G_{i}+e_{i j}$

where

$y_{i j}$ is the observed value of $j^{\text {th }}$ individual of genotype $i$,

$\mu$ is the mean of observed values,

$G_{i}$ is the practical value of the genotype $i$ and

$e_{i j}$ is the random residual effect corresponding to the observed values.

Note: The effect of the surrounding environment was included in the unexpected error.

\section{Results}

\section{PCR results and analysis}

Three TrLEP fragments with the same genotype through amplification by the same primer were sequenced three times. The PCR products of primers L2 and L3 presented polymorphism (Figure 1). Comparison of the sequences with the known TrLEP sequence (GenBank accession no.: NM_001032725) showed two polymorphic sites. Both C232G mutation and C310T mutation are located in an open reading frame (ORF). For the SNP $\mathrm{C} 232 \mathrm{G}$, the $\mathrm{C}$ and $\mathrm{G}$ are at the third position of the codons $\mathrm{CT}(\mathrm{U}) \mathrm{C}$ and $\mathrm{CT}(\mathrm{U}) \mathrm{G}$. Both the codons encode leucine (Leu). For the SNP C310T, the $\mathrm{C}$ and $\mathrm{T}$ are at the third position of the codons GAC and GAT (U), respectively. Both the codons encode Aspartic acid (Asp), representing synonymous mutation.



Figure 1 Band patterns for the two SNPs (a) Genotypes of primer L2; (b) Genotypes of primer L3

To identify the three genotypes generated by primer L2, the PCR fragments' sequence, which has the base ' $C$ ' at $232 \mathrm{nt}$, was defined as allele ' $C$.' While the sequence which has the base ' $G$ ' at 232 nt was defined as allele ' $G$ '. For primer L3, the PCR fragments' sequence, which has the base ' $C$ ' at 310nt, was defined as allele ' $C$ '. At the same time, the sequence which has the base ' $T$ ' at 310nt was defined as allele ' $T$ ' (Table 2 ).

Frequencies of genotypes and alleles of L2, and L3 were also calculated (Table 2). In L2 loci, genotype CC, CG, and GG frequencies were $61.15 \%, 35.14 \%$, and $3.71 \%$, respectively. Allele $\mathrm{C}$ and $\mathrm{G}$ frequencies were $78.72 \%$ and $21.28 \%$, respectively. In L3 loci, genotype CC, CT, and $\mathrm{TT}$ frequencies were $47.64 \%, 43.58 \%$, and $8.81 \%$, respectively. Allele C, and G frequencies were $69.43 \%$ and $30.57 \%$, respectively.

Table 2 SNPs in T. rubripes leptin gene: genotype and allele frequencies

\begin{tabular}{ccccc}
\hline SNP & Position & Mutation type & Genotype frequencies & Allele frequencies \\
\hline C310T & exon & Synonymous (GAC $\rightarrow$ CAT) & CC $(47.64 \%) ; \mathrm{CT}(43.58 \%) ; \mathrm{TT}(8.8 \%)$ & $\mathrm{C}(69.43 \%) ; \mathrm{T}(30.57 \%)$ \\
$\mathrm{C} 232 \mathrm{G}$ & exon & Synonymous (CTC $\rightarrow \mathrm{CTG})$ & $\mathrm{CC}(61.15 \%) ; \mathrm{CG}(35.14 \%) ; \mathrm{GG}$ & $\mathrm{C}(78.72 \%) ; \mathrm{G}(21.28 \%)$ \\
\hline
\end{tabular}


The second structure of TrLEP MRNA

All the second structures of TrLEP mRNA, C232G mutation (G-mRNA), and C310T mutation ( $T-m R N A$ ) were predicted by RNA structure (Figure $\mathbf{2}$ ). After $\mathrm{C}$ mutated $\mathrm{T}$ at $310 \mathrm{nt}$, the second structure of T-mRNA had a minor change that only one stem-loop structure was different (Figure 2a and Figure 2c). But when 232 nt of TrLEP MRNA was G, G-mRNA second structure changed significantly and the original stem-loop structures were broken basically (Figure $\mathbf{2 a}$ and Figure $\mathbf{2 b}$ ).

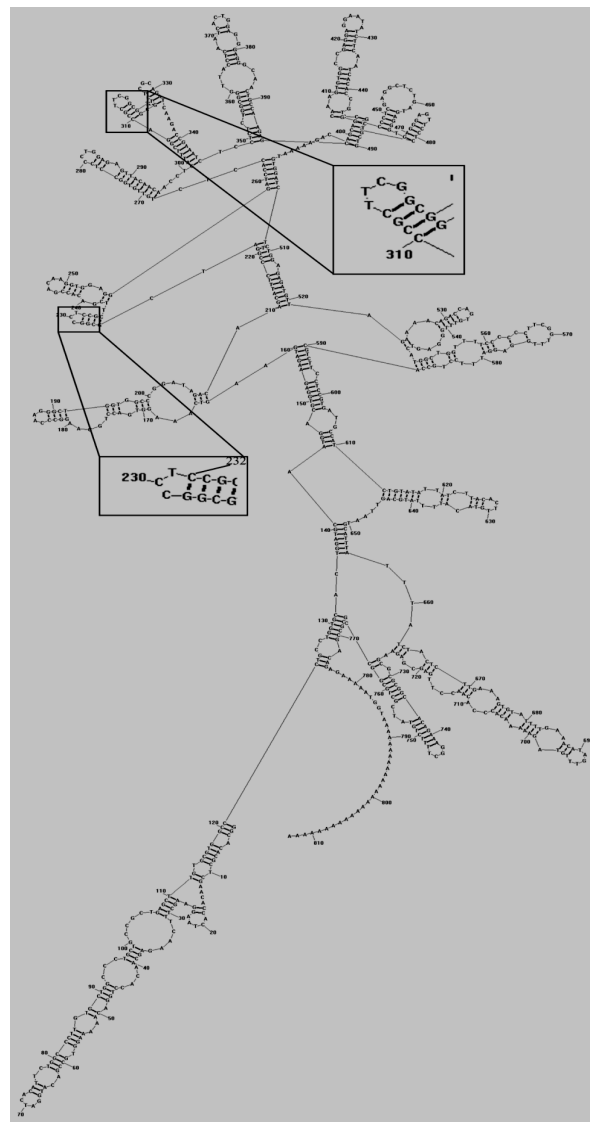

(a)

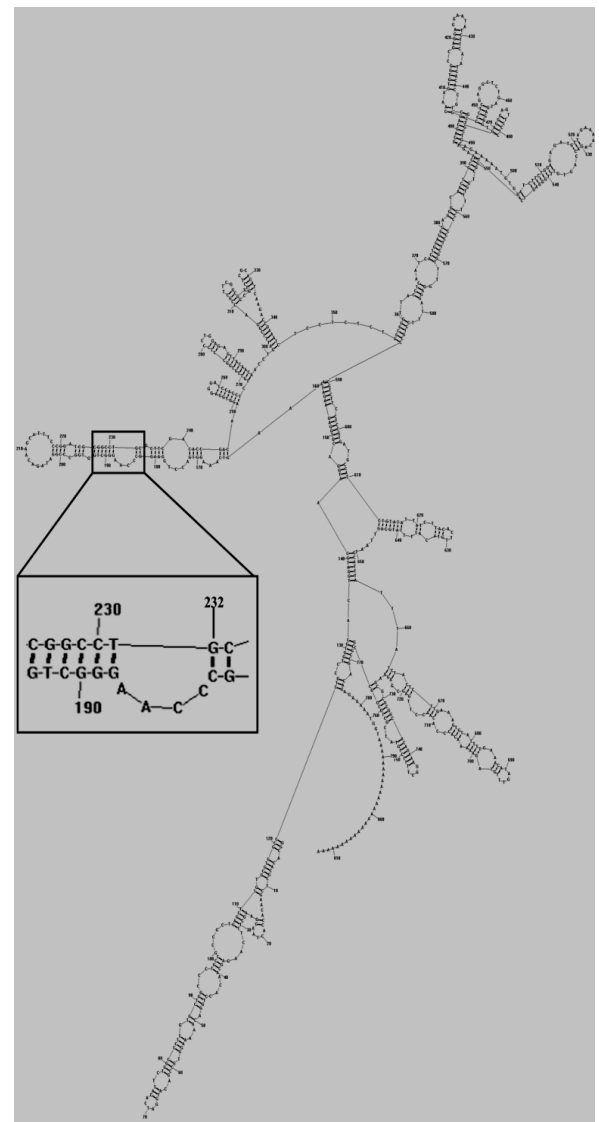

(b)

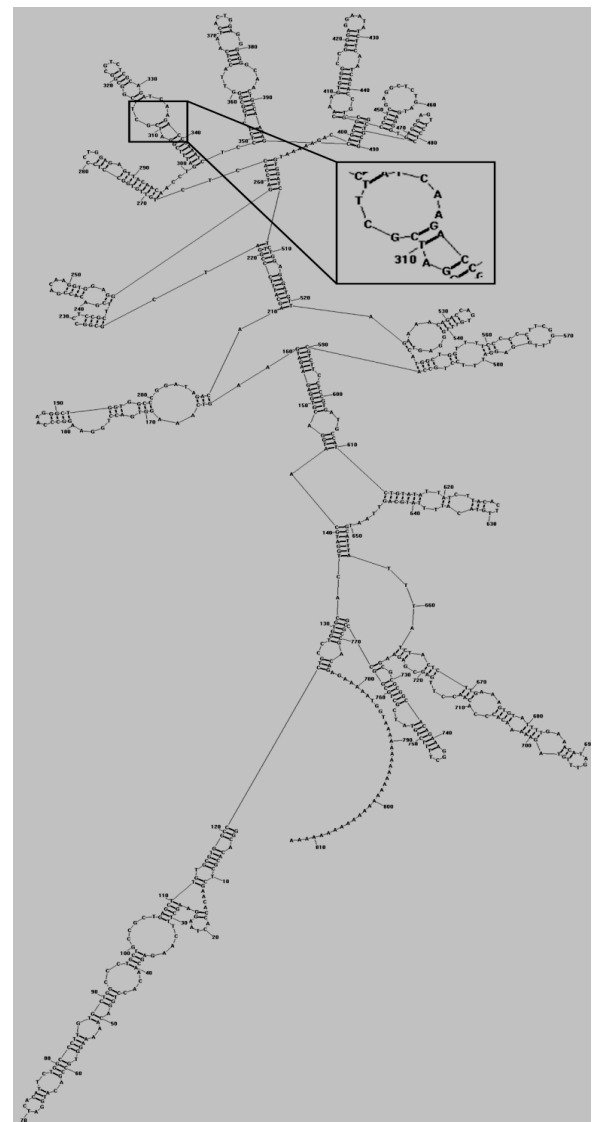

(c)

Figure 2 Comparison of the second structure of three mRNAs, including leptin mRNA, C232G mutation mRNA and C310T mutation mRNA of T. rubripes LEP gene. (a) The second structure of leptin mRNA;(b) The second structure of C232G mutation mRNA; (c) The second structure of C310T mutation mRNA.

Analysis of the association between different genotypes of the TrLEP and growth traits

The association analysis of the two loci within the TrLEP, with the growth traits, was carried out using one-way ANOVA. Three loci (L1, L4, and L5) did not find SNPs. Other loci (L3) did not show any significant effects on the examined traits in T. rubripes. L2 was significantly associated with body length, body weight, $A B L$, and ABW. Furthermore, multiple comparison analysis was performed in three genotypes of $L 2$. Results showed that the $T$. rubripes with genotype CC of L2 had significantly higher body length, body weight, $A B L$, and $A B W$ than those of genotype GG and CG (Table 3 ). 
Table 3 Analysis of the SNP polymorphism of primer $L 2$ and growth traits (ANOVA)

\begin{tabular}{ccccccc}
\hline Genotype & $\mathrm{N}^{\#}$ & $\begin{array}{c}\text { Body } \\
\text { weight(g) }\end{array}$ & Body length $(\mathrm{mm})$ & Body height $(\mathrm{mm})$ & ABL $(\mathrm{mm} / \mathrm{d})$ & $A B W(\mathrm{~g} / \mathrm{d})$ \\
\hline CC & 181 & $20.216 \pm 7.881^{\mathrm{a}}$ & $96.221 \pm 12.122^{\mathrm{a}}$ & $17.403 \pm 2.936^{\mathrm{a}}$ & $0.943 \pm 0.119^{\mathrm{a}}$ & $0.198 \pm 0.0773^{\mathrm{a}}$ \\
CG & 104 & $16.680 \pm 6.855^{\mathrm{ab}}$ & $90.894 \pm 11.044^{\mathrm{ab}}$ & $16.125 \pm 2.635^{\mathrm{a}}$ & $0.891 \pm 0.108^{\mathrm{ab}}$ & $0.164 \pm 0.0672^{\mathrm{ab}}$ \\
GG & 11 & $14.687 \pm 3.046^{\mathrm{b}}$ & $89.000 \pm 5.329^{\mathrm{b}}$ & $16.272 \pm 2.370^{\mathrm{a}}$ & $0.873 \pm 0.0522^{\mathrm{b}}$ & $0.144 \pm 0.0299^{\mathrm{b}}$ \\
\hline
\end{tabular}

${ }^{\#} \mathrm{~N}$ is the numbers of $T$. rubripes individuals. The data are presented as the mean \pm SE of the three independent Genotype populations. $a, b$, ab Within the same column of each Genotype with different letters are significantly different ( $P$-value $<0.05)$.

\section{Discussion}

Single nucleotide polymorphisms (SNPs) is the most frequently occurring form of variation in the animal genome. Many genes have many SNPs, which are mainly used in the studies of disease, even in very small samples (Constantine et al., 2008). By choosing "tag" SNPs, the SNPs can also be used to study the association between them and the production traits. This is an increasingly common approach to genetic association studies. This approach assumes that the variant and its haplotype are relatively in the general population and will be ascertained (Constantine et al., 2008). The candidate gene approach is a powerful method for investigating associations of gene polymorphisms with economically essential traits in farm animals (Rothschild and Soller, 1997). Many studies have examined growth, development, and immune function traits using the candidate gene approach in animals (Wang et al.,2010; Li et al.,2010; Gorissen et al., 2009). In our study, the LEP gene was selected as a candidate gene to investigate associations of gene polymorphisms with growth in cultured populations of $T$. rubripes.

Here we examined the presence of two TrLEP SNPs (C232G and C310T) in T. rubripes. It is, to our knowledge, the first report of significant association of these polymorphisms with growth traits in $T$. rubripes. In C232G mutation, $T$. rubripes with genotype CC of $L 2$ had significantly higher body length, body weight, $A B L$, and ABW than genotype GG and CG, though this SNP was a synonymous mutation. Some other studies have shown the critical role of the LEP in body growth using SNPs. Kennes et al. (2001) found that two SNPs (A2845T and T3469C) in the LEP gene had a significant association with intake and growth rate in landrace pigs.

Buchanan et al. (2002 and 2003) found more excellent carcass fat and LEP mRNA expression in cattle T-homozygous for C305T (LEP gene exon 2) that encodes an Arg-Cys change at aa-4 in the mature LEP gene. This suggested higher feed intake by TT genotypes. The LEP gene exon-3 SNP (A59V) associated with weight was identified by Kulig and Kmiec (2009) in cattle. Boucher et al. (2006) reported three LEP gene SNPs in Dorset and Suffolk lambs. A103G associated with thickness and shear force and metabolic activity of $M$. longissimus in Suffolks Zhou et al. (2009) found three SNPs in exon 3 that result in amino acid changes and could affect LEP gene structure and function. These studies showed that SNPs in the LEP gene could affect body growth. Correlation analysis between markers and traits reaching a significant level may indicate the relationship between the characteristics and certain traits. But some SNPs of the LEP gene were not significantly associated with growth traits. Amills et al. (2008) genotyped Landrace for exon-3 C3469T and found no associations between TT or TC and plasma leptin level, growth rate, or carcass fatness. Promoter region SNP does not associate with leptin expression or fatness in Durocs (Stachowiak et al., 2007). In this study, three genotypes of C310T mutation were not significantly associated with growth traits.

Synonymous mutations do not change the protein-coding genes, but they still have a role that can't be ignored ( $\mathrm{Li}$ and Zhou, 2007). C232G mutations were synonymous mutations in TrLEP in this study. The same phenomenon was found in previous studies. Kimchi-Sarfaty et al. (2007) found a "Silent" polymorphism in the MDR1 gene changed substrate specificity, whereas Montera et al. (2001) also found a silent mutation in exon 14 of the APC gene is associated with exon skipping in a FAP family. The synonymous mutations found in our studies might lead to protein with the same amino acid sequence but different structural and functional properties (Komar,2007). 
The change of the senior structure of mRNA may affect its translation efficiency. All the second structures of TrLEP mRNA, C232G mutation(G-mRNA), and C310T mutation (TmRNA) were predicted by RNA structure. The second structure of G-mRNA changed significantly, and the original stem-loop structures were broken basically. This might affect the function of the translated protein. In summary, the change of G-mRNA second structure would be a possible cause that genotype CC had significantly higher body length, body weight, $A B L$, and $A B W$ than genotype $G G$ and $C G$.

Correlation analysis between markers and traits reaching a significant level may indicate the relationship between the markers and specific traits. Thus, selective breeding based on phenotype can go to genotype-assisted selection (Wang et al.,2006). In this study, 296 cultivated $T$. rubripes individuals were screened for polymorphisms in the TrLEP using PCR-SSCP and DNA sequences. The genotype CC of primer L2 had a significantly higher body length, body weight, and absolute growth rate than genotype CG and GG $(P<0.05)$. It showed that the CC genotype in the C232G site was an advantage genotype, significantly associated with growth traits. It can be endorsed as a molecular marker for the selection of $T$. rubripes individuals for their culture. The results present evidence that the TrLEP may be selected as a candidate gene for various growth traits to be implemented in the breeding program of $T$. rubripes.

\section{Acknowledgments}

This work was supported by Dalian city's Science and Technology Innovation Fund Project (2018J12SN070).

\section{References}

Amills M., Villalba D., Tor M., Mercade A., Gallardo D., Cabrera B., Jimenez N., Noguera J., Sanchez A., Estany J., 2008. Plasma leptin levels in pigs with different leptin and leptin receptor genotypes. Journal of Animal Breeding and Genetics, 125 (4):228-233. https://doi.org/10.1111/j.1439-0388.2007.00715.x

Bakshi, A., Singh, R., Rai, U., 2022. The trajectory of leptin and leptin receptor in vertebrates: Structure, function, and regulation. Comp Biochem Physiol B Biochem Mol Biol, https://doi.org/10.1016/j.cbpb.2021.110652

Boucher, D., Palin, M., Castonguay, F., Gariepy, C., Pothier, F., 2006. Detection of polymorphisms in the ovine leptin (LEP) gene: association of a single nucleotide polymorphism with muscle growth and meat quality traits. Canadian Journal of Animal Science, 86 (1) :31-35.

Bruggeman, V., Onagbesan, O., Decuypere, E., 2000. Bodyweight, fat content, liver weight, and plasma leptin concentrations in broiler breeder females reared under ad libitum feeding, restricted feeding, or combinations of both until the age of the first egg. British Poultry Science, 41 (suppl. 1): 57-59.

Buchanan, F., Fitzsimmons, C., Van Kessel, A., Thue, T., Inkelman-Sim, D., Schmutz, S., 2002. Association of a missense mutation in the bovine leptin gene with carcass fat content and leptin mRNA levels. Genetics Selection Evolution, 34(1):105-116. https://doi.org/10.1186/1297-9686-341-105

Buchanan, F., Van Kessel, A., Waldner, C., Christensen, D., Laarveld, B., Schmultz, S., 2003. An association between a leptin single nucleotide polymorphism and milk and protein yield. Jl Dairy Science, 86(10), 3164-3166. https://doi.org/10.3168/jds.S0022-0302(03)73918-6

Chisada, S., Kurokawa, T., Murashita, K., Rønnestad, I., Taniguchi, Y., Toyoda, A., Sakaki, Y., Takeda, S., Yoshiura, Y., 2014. Leptin receptor-deficient (knockout) medaka, Oryziaslatipes, show chronically up-regulated levels of orexigenic neuropeptides, elevated food intake and stage specific effects on growth and fat allocation. Gen Comp Endocrinol, 195: 9-20

Constantine, C., Gurrin, L., McLaren, C., Bahlo, M., Anderson, G., Vulpe, C., Forrest, S., Allen, K., Gertig, D., 2008. SNP selection for genes of iron metabolism in a study of genetic modifiers of hemochromatosis. BMC Med Genet, https://doi.org/10.1186/1471-2350-9-18

Delavaud , C., Bocquier, F., Chilliard, Y., Keisler, D., Gertler, A., Kann, G., 2000. Plasma leptin determination in ruminants: effect of nutritional status and body fatness on plasma leptin concentration assessed by a specific RIA in sheep. J Endocrinol,165(2): 519-526. https://doi.org/10.1677/joe.0.1650519 
Gorissen, M., Bernier, N., Nabuurs, S., Flik, G., Huising, M., 2009. Two divergent leptin paralogues in zebrafish (Danio rerio) that originate early in teleostean evolution. J Endocrinol, 201(3): 329-339. https://doi.org/10.1677/JOE-09-0034

Heymsfield, S., Greenberg, A., Fujioka, K., Dixon, R., Kushner, R., Hunt, T., Lubina, J., Patane, J., Self, B., Hunt., McCamish M., 1999. Recombinant leptin for weight loss in obese and lean adults: a randomized, controlled, dose-escalation trial. JAMA, 282(16):1568-1575. https://doi.org/10.1001/jama.282.16.1568

Johnson, R., Johnson, T., Londraville, R., 2000. Evidence for leptin expression in fishes. J ExpBiol, 286(7):718-724. https://doi.org/10.1002/(sici)1097-010x(20000601)286:7<718: :aidjez6>3.0.co;2-i

Kennes, Y., Murphy, B., Pothier, F., Palin, M., 2001. Characterization of swine leptin (LEP) polymorphisms and their association with production traits. Animal Genetics, 32(4):215-218. https://doi.org/10.1046/j.1365-2052.2001.00768.x

Kimchi-Sarfaty, C., Oh, J., Kim, I., Sauna, Z., Calcagno, A., Ambudkar, S., Gottesman M., 2007. A "silent" polymorphism in the MDR1 gene changes substrate specificity. Science, 315(5811):525-528. https://doi.org/10.1126/science.1135308

Komar, A., 2007. Silent SNPs: impact on gene function and phenotype. Pharmacogenomics, 8(8), 1075-1080. https://doi.org/10.2217/14622416.8.8.1075

Kulig, H., Kmiec, M., 2009. Association between leptin gene polymorphisms and growth traits in Limousin cattle. Russian Journal of Genetics, 45 (6) : 738-741.

Kurokawa, T., Uji, S., Suzuki, T., 2005. Identification of cDNA coding for a homologue to mammalian leptin from pufferfish, Takifugu rubripes. Peptides, 26 (5) : 745-750. https://doi.org/10.1016/j.peptides.2004.12.017

Lee, Y., 2009. The role of leptin-melanocortinsystem and humanweightregulation: lessons from experiments of nature. Ann Acad Med Singapore, 38(4):34-44.

Levin, N., Nelson, C., Gurney, A., Vandlen, R., de Sauvage, F., 1996. Decreased food intake does not completely account for adiposity reduction after ob protein infusion. Proc Natl Acad Sci, 93(4):1726-1730. https://doi.org/10.1073/pnas.93.4.1726

Li, G., Liang, X., Guangzhao, Q., Yu, Y., Lai, K., 2010. Gene structure, recombinant expression and functional characterization of grass carp leptin. Gen Comp Endocrinol, 166(1):117-127. https://doi.org/10.1016/j.ygcen.2009.10.009

Li, Y., Zhou, Y., 2007. Bioinformatics methods and resources for SNP functional analysis. Computer Simulation, 24, 297-300.

Lujan, M., Krzemien, A., Reid, R., Van Vugt, D., 2006. Effect of leptin administration on ovulation in food-restricted rhesus monkeys. Neuroendocrinology, 84(2)103-114. https://doi.org/10.1159/000097071

Montera, M., Piaggio, F., Marchese, C., Gismondi, V., Stella, A., Resta, N., Varesco, L., Guanti, G., Mareni, C., 2001. A silent mutation in exon 14 of the APC gene is associated with exon skipping in a FAP family. J Med Genet, 38(12):863-867. https://doi.org/10.1136/jmg.38.12.863

Murashita, K., Uji, S., Yamamoto, T., Rønnestad, I., Kurokawa, T., 2008. Production of recombinant leptin and its effects on food intake in rainbow trout (Oncorhynchus mykiss). Comp Biochem Physiol B Biochem Mol Biol, 150(4):377-84. https://doi.org/10.1016/j.cbpb.2008.04.007

Reuter, J.S., Mathews, D.H., 2010.RNAstructure: software for RNA secondary structure prediction and analysis. BMC Bioinformatics, 11:129. https://doi.org/10.1186/1471-2105-11-129

Rothschild, M., Soller, M., 1997. Candidate gene analysis to detect traits of economic importance in domestic livestock. Probe, 8:13-20.

Stachowiak M., Mackowski M., Madeja Z., Szydlowski M., Buszka A., Kaczmarek P.,Rubis B., Mackowiak P., Nowak K., Switonski M., 2007. Polymorphism of the porcine leptin gene promoter and analysis of its association with gene expression and fatness traits. Biochemical Genetics, 45(3-4):245-253. https://doi.org/10.1007/s10528-006-9070-x

Wang, G., Wu, D., 2006. Correlation analysis of microsatellite DNA markers with wool traits in liangshan semi-fine wool sheep. Hereditas, 28(12):1505-1512. https://doi.org/10.1360/yc-0061505

Wang, X., Meng, X., Song, B., Qiu, X., Liu, H., 2010. SNPs in the myostatin gene of the mollusk Chlamysfarreri: association with growth traits. Comp Biochem Physiol B Biochem Mol Biol, 155(3):327-330. https://doi.org/10.1016/j.cbpb.2009.12.001

Wang, Y., Wang, X., Meng, X., Wang, H., Jiang, Z., Qiu,X., 2014. Identification of two SNPs in myostatin (MSTN) gene of Takifugurubripes and their association with growth traits, Molecular and Cellular Probes, 28(4):200-203. https://doi.org/10.1016/j.mcp.2014.03.006 
Wei, Y., Huang, H., Meng, Z., Zhang, Y., Luo, J., Chen, G., Lin, H., 2013. Single nucleotide polymorphisms in the leptin-a gene and associations with growth traits in the orange-spotted grouper (Epinepheluscoioides). Int J Mol Sci, 14(4):8625-8637. https://doi.org/10.3390/ijms14048625

Won, E., Baltzegar, D., Picha, M., Borski, R., 2012. Cloning and characterization of leptin in a Perciform fish, the striped bass (Moronesaxatilis): Control of feeding and regulation by nutritional state. Gen Comp Endocrinol, 178(1):98-107. https://doi.org/10.1016/j.ygcen.2012.04.019

Yuan, X.C., Liang, X.F., Cai, W.J., Li, A.X., Huang, D., He, S., 2020. Differential Roles of Two Leptin Gene Paralogues on Food Intake and Hepatic Metabolism Regulation in Mandarin Fish. Front Endocrinol (Lausanne), 11:438. https://doi.org/10.3389/fendo.2020.00438

Zhang, F., Basinski, M., Beals, J., Briggs, S., Churgay, L., Clawson, D., DiMarchi, R., Furman,T., Hale, J., Hsiung H., Schoner, B., Smith, D., Zhang, X., Wery, J., Schevitz, R., 1997. Crystal structure of the obese protein leptin-E100. Nature, 387(6629):206-209. https://doi.org/10.1038/387206a0

Zhang, Y., Chua, S. Jr., 2017. Leptin Function and Regulation. Compr Physiol, 8(1):351-369. https://doi.org/10.1002/cphy.c160041

Zhang, Y., Proenca, R., Maffei, M., Barone, M., Leopold, L., Friedman, J., 1994. Positional cloning of the mouse obese gene and its human homologue. Nature, 372(6505):425-32. https://doi.org/10.1038/372425a0

Zhou, H., Hickford, J., Gong, H., 2009. Identification of allelic polymorphism in the ovine leptin gene. Molecular Biotechnology, 41(1):22-25.https://doi.org/10.1007/s12033-008-9090-3 